\title{
Description of the female of Ctenodontina nairae Vieira (Diptera, Asilidae, Asilinae), with new distribution records
}

\author{
Rodrigo Vieira \\ Instituto Nacional de Pesquisas da Amazônia - INPA, CBIO - Programa de Pós-Graduação em Entomologia, Campus II, 69060-000 Manaus-AM, \\ Brazil. rodrigo08vieira@gmail.com
}

\begin{abstract}
Description of the female of Ctenodontina nairae Vieira (Diptera, Asilidae, Asilinae), with new distribution records. The female of Ctenodontina nairae Vieira, 2012 is described for the first time. Description and illustrations of the habitus, wing and terminalia of the female are provided. The distribution is extended to Bolivia and Peru.
\end{abstract}

KEYWORDS. Brachycera; Insecta; Lecania group; Neotropical; taxonomy.

Ctenodontina Enderlein is a small genus of Asilinae with Neotropical distribution (Vieira 2012a). Ctenodontina, together with Lecania Macquart and Cerozodus Bigot, make up the artificial genus group Lecania (Artigas \& Papavero 1995).

The males of Ctenodontina are characterized by an epandrium narrowed apically (usually terminating in a ûngerlike lobe) and distinctly shorter than sternite VIII (Fisher \& Hespenheide 1992; Fisher 2009; Vieira 2012a). In the female, the ovipositor has an apical comb of spines, and tergite VIII is broadly expanded laterally, densely setose and cupped beneath, completely obscuring sternite VIII in proûle (Fisher \& Hespenheide 1992; Fisher 2009; Vieira 2012a).

The genus includes five species, $C$. martini Fisher in Fisher \& Hespenheide, 1992 (Mexico and Guatemala), C. maya Carrera \& d'Andretta, 1953 (Peru), C. nairae Vieira, 2012 (Brazil), C. mochica Lamas, 1973 (Peru), and C. pectinatipes Enderlein, 1914 (Colombia) (Vieira 2012a), all of them known only from adults. Ctenodontina nairae was described from the state of Amazonas and the male is recognized by the hind femur without swelling on the ventral surface of its apical threequarters, bearing a group of spine-like setae or subtuberculate spines and epandrium strongly excavated laterally with finger-like lobe placed ventrally. The apex of the finger-like lobe is pointed in lateral view (Vieira 2012a).

In this paper, the female of $C$. nairae is described and new records are provided.

\section{MATERIAL AND METHODS}

This study is based on the examination of specimens housed at Coleção Zoológica Prof. Paulo Bürhnheim, Departamento de Biologia, Universidade Federal do Amazonas (CZPB), Manaus, Amazonas state, Brazil; Instituto Nacional de Pesquisas da Amazônia (INPA), Manaus, Amazonas state, Brazil and Zoologische Staatssammlung
Munich (ZSM), Munich, Bavaria state, Germany. Morphological terminology follows Cumming \& Wood (2009). Vieira's (2012b) techniques were used to examine the terminalia. After study and illustration, the detached parts were placed in microvials with glycerin and pinned with their respective specimen. The female of $C$. nairae was associated with the male based on the external morphology of the body. In addition, one male and one female were collected in the same locality. The label data is cited in full, with the original spellings, punctuations, and dates. Information presented within square brackets is complementary data not included on the labels. Data for the same specimen but from different labels are separated by slashes (/).

\section{TAXONOMY}

Ctenodontina nairae Vieira, 2012

(Figs. 1-5)

Ctenodontina nairae Vieira, 2012: 2, figs. 2a-2f, 3a, 3b, 4a-4j

Female description. Similar to male (Fig. 1), except for body length: 17.5-20.7 mm, wing 13.2-13.7 mm (Fig. 2). Head. Postpedicel dark brown; vertex black and golden tomentose; mystacal macrosetae black on the upper half of the facial swelling and yellow on the lower half; occipital setae white to yellowish; palpus with yellow and brown setae. Legs. Middle tibia with two anterior stripes, one yellow and one brown; first tarsomere, of the fore and middle leg, yellow, other tarsomeres brown; hind tarsus black; middle femur with 3-4 black macrosetae anteriorly, 2-3 black macrosetae and one yellow macroseta posteriorly and 9 black macrosetae ventrally; hind femur with one black macroseta anteriorly and 2 black macrosetae anteroventrally; fore tibia with 4 black macrosetae dorsally; hind tibia with one black preapical 


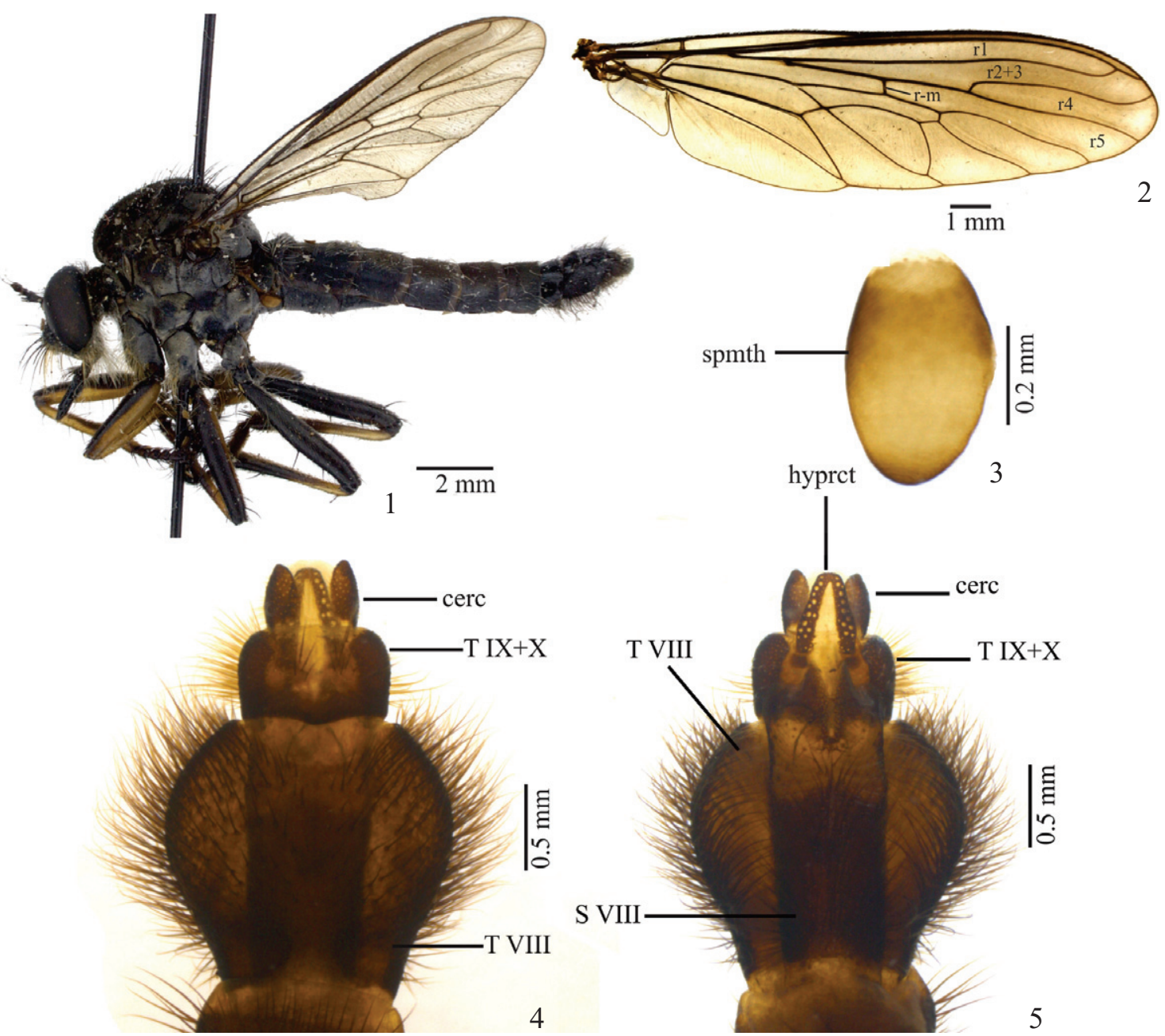

Figs. 1-5. Ctenodontina nairae Vieira, 2012. Female. 1. Habitus, lateral view; 2. Wing; 3. Capsule of spermathecae; 4. Ovipositor, dorsal view; 5. Ovipositor, ventral view. Abbreviations: cerc: cercus; hyprct: hypoproct; spmth: spermathecae; S VIII: sternite VIII; T VIII: tergite VIII; T IX + X: tergite IX $+\mathrm{X}$.

macroseta anteroventrally. Abdomen. Black, tergites II-VI slightly gray tomentose laterally; tergites II-III without lateral marginal macrosetae. Terminalia. Two oval sclerotized spermathecal capsules (Fig. 3). Tergite VIII broadly expanded laterally (Figs. 4, 5); tergite IX $+\mathrm{X}$ membranous medially (Fig. 4 ); median sclerite at posterior end of furca (remnant of tergite IX) absent.

Type-material examined. Holotype: BRASIL, Amazonas, Coari, rio Urucu, Ig.[arapé] Marta-3, 450’0,73"S, 6502’37"W, 14-25.viii.1993, P.F. Bührnheim et al. col./Armadilha de Malaise/Holótipo Ctenodontina nairae Vieira (O' CZPB). Paratype: BRASIL, Amazonas, Coari, rio Urucu, Angelim, 5³'33"S, 65¹4'48"W, 23.xi-02.xii.1992, P.F. Bührnheim and N.O. Aguiar/Armadilha de Shannon/Parátipo Ctenodontina nairae Vieira (O' INPA)

Additional material examined. PERU, Laristhal, [Paso de Lares], 18.viii.[19]03, 800m, (1 \& ZSM); BOLIVIA, Mapiri, [Larecaja province], [15³0'87"S 6824'12"W], 23.i.[19]03, Sarampioni, 700m/Platynaedium o sp. (1 ᄋ INPA); Same label data, except: 23.ii.[19]03/Platynaedium Ơ sp./Bolivia, Platynaedium ( 1 Ơ ZSM). In addition to the material listed above, 3 o and $2 O^{\prime \prime}(\mathrm{ZSM})$ of $C$. nairae lacking locality labels have been examined
Comments. The females of C. pectinatipes and C. mochica are unknown (Enderlein 1914; Lamas 1973). The males of these species possess the femora completely light yellow brown. Ctenodontina maya possess the fore and mid femora black on basal half and yellow on distal half (Carrera and d'Andretta, 1953). Ctenodontina nairae can be separated of these species by the fore and mid femora black dorsally and anteriorly, ventrally and posteroventrally yellowish, narrow black except apex of mid femora posteroventrally and hind femora wholly black (Vieira 2012a). Furthermore, C. nairae has the tergites II-VI laterally slightly gray tomentose (Vieira 2012a), while C. martini has lateral margins of all tergites more extensively gray (Martin 1975).

Distribution. BRAZIL: Amazonas; PERU: Laristhal; BOLIVIA: Mapiri.

\section{ACKNOWLEDGMENTS}

To Fundação de Amparo à Pesquisa do Estado do Amazonas (FAPEAM) and Conselho Nacional de Desenvolvi- 
mento Científico e Tecnológico (CNPq) for financial support to the Project PRONEX, Edital 016/2006, Proc. 1437/ 2007. CNPq/PNPD Processo $n^{\circ}$ : 560987/2010-2 and FAPEAM EDITAL N. 022/2013 - FIXAM/AM No Processo: 062.00745/2014. To Dr. Marion Kotrba and Dr. Dieter Doczkal (Zoologische Staatssammlung Munich) for the loan of the specimens. Thanks to DAAD (Deutscher Akademischer Austausch Dienst) for financial support to travel to Germany.

\section{REFERENCES}

Artigas, J.N. \& Papavero, N. 1995. The American genera of Asilidae (Diptera): Keys for identification with an atlas of female spermathecae and other morphological details. IX.10. Subfamily Asilinae Leach - Lecania group, with a catalogue of the Neotropical species. Theoria 4: 33-56.

Carrera, M. \& Andretta, M.A.V. de. 1953. Asilideos do Peru (Diptera). Papéis Avulsos do Departamento de Zoologia. Secretaria da Agricultura 11: $63-78$.

Cumming, J.M. \& Wood, D.M. 2009. Adult morphology and terminology, p. 9-50. In: Brown, B.V., Borkent, A., Cumming, J.M., Wood, D.M., Woodley, N.E. \& Zumbado, M.A. (eds.). Manual of Central American Diptera. Volume 1. Ottawa, National Research Council Research Press, 950 p.
Enderlein, G. 1914. Dipterologische Studien. XI. Zur Kenntnis tropischer Asiliden. Zoologischer Anzeiger 44: 241-263.

Fisher, E. 2009. Asilidae (Robber flies, Assassin flies, Moscas Cazadoras, Moscas Ladronas), p. 585-632. In: Brown, B.V., Borkent, A., Cumming, J.M., Wood, D.M., Woodley, N.E. \& Zumbado, M.A. (eds.). Manual of Central American Diptera. Volume 1. Ottawa, National Research Council Research Press, 950 p.

Fisher, E.M. \& Hespenheide, H.A. 1992. Taxonomy and biology of Central American robber flies with an illustrated key to the genera (Diptera, Asilidae), p. 611-632. In: Quintero Arias, D. \& Aiello, A. (eds.). Insects of Panama and Meso-America. Oxford, Oxford University Press, $714 \mathrm{p}$.

Lamas, G. 1973. Some comments on the genus Ctenodontina Enderlein (Diptera, Asilidae), with the description of a new species from coastal Peru. Papéis Avulsos de Zoologia 26: 275-280.

Martin, C.H. 1975. The generic and specific characters of four old and six new Asilini genera in the western United States, Mexico and Central America (Diptera: Asilidae). Occasional Papers of the California Academy of Sciences 119: 1-107.

Vieira, R. 2012a. Ctenodontina Enderlein, 1914 (Diptera, Asilidae, Asilinae): First record for Brazil and description of a new species. International Scholarly Research Network ISRN Zoology 12: 1-6.

Vieira, R. 2012b. A new species of Leinendera Carrera, 1945 (Diptera, Asilidae, Asilinae) from Brazil. Biota Neotropica 12: 1-7.

Received 1 July 2014; accepted 20 August 2014

Associate Editor: Marcia S. Couri 